\title{
Analisis Usaha Beberapa Produk Olahan Perikanan di CV. Fania Food Kota Gede Daerah Istimewa Yogyakarta
}

\author{
[Business Analysis Of Some Fished Products In CV. Fania Food \\ Kota Gede Special Region Of Yogyakarta]
}

\author{
Anwar Akbar Amdar, Pigoselpi Anas, Tatty Yuniarti \\ Jurusan Penyuluhan Perikanan-Sekolah Tinggi Perikanan \\ Jalan Cikaret No.2 Bogor Selatan, Kota Bogor
}

\begin{abstract}
Abstrak
Peningkatan angka konsumsi ikan nasional yang telah menyentuh $50 \mathrm{~kg}$ per kapita per tahun pada tahun 2018, memberikan dampak positif pada usaha pengolahan perikanan. Tingginya permintaan memberikan dampak bagi pelaku usaha perikanan dalam peningkatan kesejahteraan serta membuka lapangan kerja di masyarakat. Dalam rangka meningkatan angka konsumsi ikan, maka dilakukan diversifikasi olahan untuk meningkatkan cita rasa serta nilai jual pada olahan tersebut. Berbagai diversivikasi olahan telah terkenal ditengah masyarakat diantaranya produk olahan bakwan bandeng, bakso bandeng, nugget bandeng, kaki naga, otak-otak bandeng, galantin, otak-otak ikan dan lain lain. Tujuan penelitian adalah untuk membandingkan analisis usaha tujuh olahan perikanan pada CV. Fania Food Kota Gede, Yogyakarta. Kajian dilakukan dengan metode survei dan magang di CV. Fania Food selama 21 hari dan dilakukan studi literatur sebagai data sekunder pada isi kajian. Analisis usaha yang telah dilakukan mendapatkan hasil bahwa semua produk olahan dapat dinyatakan layak dengan nilai $\mathrm{R} / \mathrm{C}$ ratio diatas 1 yaitu bakwan $(1,38)$, bakso $(2,01)$, nugget $(1,16)$, kaki naga $(1,37)$, otak-otak ikan $(2,23)$, galantin $(1,85)$, otakotak bandeng $(1,73)$. Produk dengan pendapatan lebih besar dari biaya produksi yaitu produk olahan otak-otak ikan dengan nilai $\mathrm{R} / \mathrm{C}$ ratio 2,23 , adapun produk dengan keuntungan tertinggi yaitu otak-otak bandeng dengan keuntungan $\mathrm{Rp} 20.937 .482$ dalam satu bulan produksi.
\end{abstract}

Kata kunci : analisis usaha, diversivikasi, R/C.

\section{Abstract}

An increase in the national fish consumption figure which has touched $50 \mathrm{~kg}$ per capita per year in 2018, has a positive impact on the fisheries processing business. The high demand has an impact on fisheries businesses in improving welfare and opening up jobs in the community. In order to increase the number of fish consumption, processed diversification is carried out to improve the taste and selling value of the processed products. Various diversification of processed have been famous in the middle of the community including processed products of bakwan milkfish, milkfish meatballs, milkfish nuggets, dragon legs, milk brains, galantin, fish brains and others. The purpose of the study was to compare the seven business analyzes of processed fisheries in the CV. Fania Food Kota Gede, Yogyakarta. The study was conducted by survey method and an internship at CV. Fania Food for 21 days and conducted a literature study as secondary data on the content of the study. The business analysis that has been carried out shows that all processed products can be declared feasible with an $\mathrm{R} / \mathrm{C}$ ratio above 1 , namely Bakwan $(1,38)$, Bakso $(2,01)$, Nugget $(1,16)$, Kaki Naga $(1,37)$, Otak-otak Ikan $(2,23)$, Galantin $(1,85)$, Otak-otak Bandeng $(1,73)$. Products with greater income than production costs are processed Otak-otak Ikan with an $\mathrm{R} / \mathrm{C}$ ratio of 2,23 , while the product with the highest profit is Otak-otak Bandeng with a profit of Rp 20.937 .482 in one month of production.

Keywords : Business Analysis, Diversification, R/C.

\section{Penulis Korespondensi}




\section{PENDAHULUAN}

Perikanan merupakan sektor ekonomi dengan peranan dan potensi yang penting bagi perekonomian di Indonesia. Dalam pembangunan nasional, sektor perikanan berperan sebagai peningkatan devisa dengan ekspor hasil perikanan, bahan baku pendorong agroindustri, membuka kesempatan kerja, peningkatan pendapatan pelaku perikanan dan pembangunan daerah, serta peningkatan kelestarian sumber daya perikanan dan lingkungan hidup (Yudaswara 2018).

Ikan memiliki kandungan protein yang berkualitas tinggi. Protein tersebut terdiri atas asam amino esensial sebagai sumber energi tubuh, membantu pertumbuhan dan kesehatan tubuh, memperlancar proses fisiologi tubuh, dan memperkuat daya tahan tubuh. Dibandingkan produk hewani lainnya, ikan memiliki kelebihan seperti kandungan protein yang cukup tinggi yaitu $20 \%$, mudah dicerna oleh tubuh, kandungan asam-asam lemak tak jenuh dengan kadar kolestrol yang rendah, dan daging ikan memiliki sejumlah mineral seperti $\mathrm{K}, \mathrm{Cl}, \mathrm{P}, \mathrm{Cu}, \mathrm{Ca}, \mathrm{Fe}, \mathrm{S}, \mathrm{Mg}, \mathrm{Ma}$, Zn, vitamin A dan D (Hasibuan 2018).

$\begin{array}{crr}\text { Analisis } & \text { kelayakan } & \text { (feasibility } \\ \text { analysis) } & \text { merupakan } & \text { proses }\end{array}$

menentukan suatu ide bisnis yang baru dapat berlanjut menjadi usaha yang sukses sehingga dapat dikatakan menjadi bisnis yang layak atau tidak. Jika tergolong layak, maka selanjutnya penyusunan rencana bisnis yang unggul untuk mengeksploitasi ide tersebut (Heri 2017).

Ikan yang telah diolah lebih diminati konsumen karena lebih mudah serta praktis untuk dikonsumsi (ready to eat) atau dimasak (ready to cook). Melalui produk olahan tersebut, diharapkan konsumen menjadi lebih terbiasa dengan produk-produk perikanan (Kurniawan 2017). Salah satu produk perikanan yang diminati oleh masyarakat yaitu ikan bandeng. Ikan bandeng memiliki rasa cukup enak dan gurih sehingga digemari masyarakat, dan memiliki harga yang terjangkau bagi segala lapisan masyarakat. Ikan bandeng termasuk sebagai ikan berprotein tinggi dan berkadar lemak rendah (E. Susanto 2010). Terdapat beberapa produk perikanan yang berasal dari bahan baku ikan bandeng (Chanos chanos) antara lain bakwan bandeng, bakso bandeng, nugget bandeng, kaki naga, otak-otak bandeng, galantin dan otak-otak ikan.

Olahan-olahan tersebut memiliki prospek pasar yang cerah karena dapat 
dijangkau seluruh lapisan masyarakat karena harga jual yang murah dan rasanya yang enak sehingga disukai oleh berbagai kalangan baik itu anak-anak maupun orang dewasa. Hal ini mengakibatkan permintaan hasil olahan perikanan mengalami peningkatan dari tahun ke tahun. Tujuan kajian ini untuk menganalisis usaha olahan perikanan yang terdapat di CV. Fania Food, Kecamatan Kota Gede, Kota Yogyakarta". Produk yang dianalisis adalah tujuh dari 30 produk olahan yang diproduksi di CV. Fania Food, Kecamatan Kota Gede, Kota Yogyakarta.

\section{BAHAN DAN METODE}

Kegiatan ini dilaksanakan dengan metode magang dan studi kasus dilakukan di CV. Fania Food Kota Gede mengenai manajemen usaha tujuh pengolahan dari 30 jenis pengolahan yang ada. Pengolahan tersebut antara lain bakwan bandeng, bakso bandeng, nugget bandeng, kaki naga, otak-otak bandeng, galantin dan otak-otak ikan. Data yang diperoleh dalam bentuk data primer dan data sekunder. Data primer diperoleh dari hasil wawancara dengan pemimpin olahan di CV Fania Food. Data yang termasuk ke dalam data primer yaitu jumlah produksi, harga jual, harga bahan baku, biaya listrik, biaya tenaga kerja, dan biaya investasi. Data sekunder ini merupakan data yang bersifat mendukung keperluan data primer seperti buku-buku, literatur, dan bacaan.

\section{Analisis Data}

Analisis Biaya Produksi

Biaya produksi adalah semua pengeluaran yang dilakukan perusahaan untuk memproduksi barang/jasa. Biaya produksi terdiri dari yaitu biaya tetap dan biaya variabel. Biaya tetap yaitu biaya yang penggunaannya tidak habis dalam satu masa produksi. Adapun biaya variabel (tidak tetap) yaitu biaya yang habis dalam satu masa produksi $(\mathrm{H}$. Susanto 2010). perhitungan biaya produksi sebagai berikut :

$$
\text { Biaya } \text { Total }=\text { Biaya Tetap }+ \text { Biaya }
$$$$
\text { Variabel }
$$

\section{Analisis Pendapatan Usaha}

Pendapatan usaha yang diperoleh dan harga jual produk dapat dihitung dengan rumus : (Geffken, 2017).

$$
\text { Pendapatan }=\text { Jumlah Produksi } \times \text { Harga }
$$$$
\text { Jual Produk }
$$

\section{Analisis Keuntungan Keuntungan}

Perhitungan keuntungan dalam usaha digunakan rumus : (Geffken, 2017)

$$
\begin{aligned}
\text { Keuntungan }= & \text { Pendapatan }- \text { Biaya } \\
& \text { Total }
\end{aligned}
$$


Revenue - Cost Ratio (R/C)

Saparinto (2014) menjelaskan R/C Ratio yaitu perbandingan penerimaan dengan pengeluaran biaya. Bila nilai $\mathrm{R} / \mathrm{C}$ diatas satu dianggap layak, R/C dibawah satu dianggap tidak layak, sedangkan $\mathrm{R} / \mathrm{C}=1$ (Trade Off), dapat dilaksanakan atau tidak tergantung pihak yang akan melaksanakan usaha.

Analisis R/C dapat dihitung dengan rumus dibawah ini:

$$
\mathrm{R} / \mathrm{C}=\frac{\text { Total Penerimaan }}{\text { Total Biaya }}
$$

Payback Period (PP)

PP mengukur seberapa cepat investasi bisa kembali dalam satuan waktu (hari, bulan dan tahun). PP membandingkan initial investment (investasi awal) dengan operational net cash inflow (taksiran kas bersih) per tahun. Taksiran kas masuk bersih merupakan penjumlahan dari laba bersih dan penyusutan pada tahun yang bersangkutan. (Rahardi, Regina, dan Nazaruddin 2008)

Saparinto (2014) menjelaskan analisis payback period dapat dihitung dengan rumus dibawah ini :

Payback Period $=\frac{\text { Total Investasi }}{\text { Keuntungan Dalam } 1 \text { Tahun }}$

\section{Break Even Point}

Saparinto (2014) menjelaskan BEP merupakan suatu titik dimana hasil penjualan sama dengan biaya produksi, sehingga pengeluaran dan pendapatan mengalami impas, tidak rugi dan tidak untung. Perhitungan BEP untuk menentukan batas minimal volume penjualan agar perusahaan tidak rugi. BEP juga dapat digunakan untuk merencanakan tingkat keuntungan serta pedoman dalam mengendalikan operasi yang sedang berjalan. BEP dibagi menjadi 2 yaitu BEP harga dan BEP unit, dengan rumus sebagai berikut:

$$
\begin{gathered}
\operatorname{BEP}(\mathrm{Rp})=\frac{\text { Biaya tetap }}{1-\frac{\text { Biaya variable }}{\text { Penjualan }}} \\
\operatorname{BEP}(\text { Unit })=\frac{\text { Biaya tetap }}{\text { Harga Jual-Biaya Variabel }}
\end{gathered}
$$

Return Of Invesment (ROI)

$\mathrm{ROI}$ merupakan nilai keuntungan yang diperoleh dari setiap jumlah uang yang diinvestasikan dalam periode waktu tertentu. Analisis ROI membantu perusahaan mengukur seberapa besar kemampuan dalam pengembalian modal yang telah ditanam (Rahardi et al. 2008).

Saparinto (2014) dalam analisis ROI dapat dihitung dengan rumus dibawah ini :

$$
\text { ROI }=\frac{\text { Laba Usaha }}{\text { Biaya Produksi }}
$$


Tabel 1. Rincian Biaya Investasi Pengolahan Produk Olahan Hasil Perikanan

\begin{tabular}{|c|c|c|c|c|c|c|c|}
\hline Uraian & Satuan & Jumlah & $\begin{array}{l}\text { Harga.unit }{ }^{-1} \\
\text { (Rp) }\end{array}$ & $\begin{array}{l}\text { Nilai Investasi } \\
\quad(\mathrm{Rp})\end{array}$ & $\begin{array}{l}\text { Nilai } \\
\text { Sisa }\end{array}$ & $\begin{array}{c}\text { Umur } \\
\text { Ekonomi } \\
\text { (bulan) }\end{array}$ & $\begin{array}{l}\text { Penyusuta } \\
\text { bulan }^{-1}(\mathrm{Rp})\end{array}$ \\
\hline PERIZINAN & Paket & 1 & 1.000 .000 & 1.000 .000 & 0 & 12 & 83.333 \\
\hline BANGUNAN & $\mathrm{m}^{2}$ & 80 & 1.200 .000 & 96.000 .000 & 0 & 300 & 320.000 \\
\hline \multicolumn{4}{|c|}{ Jumlah Total Investasi } & 97.000 .000 & \multicolumn{2}{|c|}{$\begin{array}{l}\text { Total biaya } \\
\text { penyusutan }\end{array}$} & 403.333 \\
\hline \multicolumn{4}{|c|}{ Investasi per produk dari 30 produk } & 3.233.333 & \multicolumn{2}{|c|}{$\begin{array}{l}\text { Penyusutan/produk } \\
\text { dari } 30 \text { produk }\end{array}$} & 13.444 \\
\hline \multicolumn{4}{|c|}{ MESIN DAN PERALATAN } & & & & \\
\hline Meja preparasi & Buah & 1 & 4.000 .000 & 4.000 .000 & 0 & 240 & 16.667 \\
\hline $\begin{array}{l}\text { Timbangan } \\
\text { kapasitas } 1 \mathrm{~kg}\end{array}$ & & 1 & 200.000 & 200.000 & 0 & 60 & 3.333 \\
\hline Mesin meat grinder & Buah & 1 & 3.500 .000 & 3.500 .000 & 0 & 120 & 29.167 \\
\hline Meat bowl cutter & Buah & 1 & 15.000 .000 & 15.000 .000 & 0 & 120 & 125.000 \\
\hline Keranjang & Buah & 6 & 25.000 & 150.000 & 0 & 60 & 2.500 \\
\hline Ember & Buah & 6 & 50.000 & 300.000 & 0 & 60 & 5.000 \\
\hline Pisau fillet & Buah & 6 & 150.000 & 900.000 & 0 & 120 & 7.500 \\
\hline Talenan & Buah & 6 & 50.000 & 300.000 & 0 & 60 & 5.000 \\
\hline Kompor gas & Buah & 2 & 400.000 & 800.000 & 0 & 120 & 6.667 \\
\hline Tabung gas $3 \mathrm{~kg}$ & Buah & 2 & 120.000 & 240.000 & 0 & 120 & 2.000 \\
\hline Dandang pengukus & Buah & 2 & 150.000 & 300.000 & 0 & 120 & 2.500 \\
\hline Sealer & Buah & 2 & 300.000 & 600.000 & 0 & 36 & 16.667 \\
\hline $\begin{array}{l}\text { Baskom stainless } \\
\text { steel }\end{array}$ & Buah & 5 & 100.000 & 500.000 & 0 & 120 & 4.167 \\
\hline Panci perebus & Buah & 3 & 200.000 & 600.000 & 0 & 120 & 5.000 \\
\hline Mesin Expired & Buah & 1 & 950.000 & 950.000 & 0 & 36 & 26.388 \\
\hline Frezeer Biasa & Buah & 5 & 2.500 .000 & 12.500 .000 & 0 & 60 & 208.333 \\
\hline Frezeer Kaca & Buah & 2 & 4.500 .000 & 9.000 .000 & 0 & 84 & 107.143 \\
\hline Spatula 1 Set & Buah & 2 & 15.000 & 30.000 & 0 & 36 & 833 \\
\hline Kipas Angin Besar & Buah & 3 & 450.000 & 1.350 .000 & 0 & 84 & 22.500 \\
\hline Mesin Pompa Air & Buah & 1 & 500.000 & 500.000 & 0 & 120 & 4.166 \\
\hline \multicolumn{4}{|c|}{ Total biaya investasi } & 51.240 .000 & \multicolumn{2}{|c|}{$\begin{array}{l}\text { Total biaya } \\
\text { penyusutan }\end{array}$} & 598.023 \\
\hline \multicolumn{4}{|c|}{ Investasi per produk dari 23 produk } & 2.227.826 & \multicolumn{2}{|c|}{$\begin{array}{l}\text { Penyusutan/produk } \\
\text { dari } 23 \text { produk }\end{array}$} & 26.001 \\
\hline Vacum Pack* & Buah & 1 & 4.500 .000 & 4.500 .000 & 0 & 60 & 75.000 \\
\hline Lemari Peniris* & Buah & 1 & 500.000 & 500.000 & 0 & 36 & 26.388 \\
\hline \multicolumn{4}{|c|}{ Total biaya investasi } & 5.000 .000 & \multicolumn{2}{|c|}{$\begin{array}{l}\text { Total biaya } \\
\text { penyusutan }\end{array}$} & 101.388 \\
\hline \multicolumn{4}{|c|}{ Investasi per produk dari 4 produk } & 1.250 .000 & \multicolumn{2}{|c|}{$\begin{array}{l}\text { Penyusutan/produk } \\
\text { dari } 4 \text { produk }\end{array}$} & 25.347 \\
\hline \multicolumn{4}{|c|}{ ALAT-ALAT KEBERSIHAN } & & & & \\
\hline Sapu & Buah & 2 & 5.000 & 10.000 & 0 & 24 & 417 \\
\hline Lap Pel & Buah & 2 & 10.000 & 20.000 & 0 & 24 & 833 \\
\hline Pengki & Buah & 2 & 7.000 & 14.000 & 0 & 24 & 583 \\
\hline Serbed & Buah & 10 & 3.000 & 30.000 & 0 & 24 & 1.250 \\
\hline \multicolumn{4}{|c|}{ Total biaya investasi } & 74.000 & \multicolumn{2}{|c|}{$\begin{array}{l}\text { Total biaya } \\
\text { penyusutan }\end{array}$} & 3.084 \\
\hline \multicolumn{4}{|c|}{ Investasi per produk dari 30 produk } & 2.466 & \multicolumn{2}{|c|}{$\begin{array}{l}\text { Penyusutan/produk } \\
\text { dari } 30 \text { produk }\end{array}$} & 102 \\
\hline \multicolumn{4}{|c|}{ PERALATAN KANTOR } & & & & \\
\hline Meja kerja & Buah & 1 & 500.000 & 500.000 & 0 & 120 & 4.167 \\
\hline Kursi & Buah & 3 & 150.000 & 450.000 & 0 & 120 & 3.750 \\
\hline Komputer & Buah & 1 & 2.500 .000 & 2.500 .000 & 0 & 120 & 20.833 \\
\hline \multicolumn{4}{|c|}{ Total biaya investasi } & 3.450 .000 & & $\begin{array}{l}\text { Biaya } \\
\text { Isutan }\end{array}$ & 28.750 \\
\hline \multicolumn{4}{|c|}{ Investasi per produk dari 30 produk } & 115.000 & \multirow{2}{*}{\multicolumn{2}{|c|}{$\begin{array}{c}\text { Penyusutan/produk } \\
\text { dari } 30 \text { produk } \\
\text { JUMLAH } \\
\text { PENYUSUTAN }\end{array}$}} & 958 \\
\hline TOTAL BIAYA & INVEST & SI KESE & URUHAN & 156.591 .826 & & & 1.133 .335 \\
\hline
\end{tabular}

\footnotetext{
Catatan : * alat yang hanya digunakan oleh olahan galantin dan otak-otak bandeng dari
} ketujuh kajian. 
Tabel 3. Rincian biaya tetap dalam satu bulan

\begin{tabular}{|c|c|c|c|c|c|}
\hline Uraian & Satuan & Jumlah & $\begin{array}{c}\text { Harga } \\
\text { Satuan (Rp) }\end{array}$ & $\begin{array}{c}\text { Jumlah } \\
\text { Biaya (Rp) }\end{array}$ & $\begin{array}{c}\text { Jumlah } \\
\text { Bulan'-1 }^{-1} \\
\text { (Rp) }\end{array}$ \\
\hline \multirow{2}{*}{$\begin{array}{l}\text { Tenaga kerja } \\
\text { penanggung jawab } \\
\text { Listrik }\end{array}$} & Orang & 2 & 1.700 .000 & 3.400 .000 & 3.400 .000 \\
\hline & Paket & $\begin{array}{c}4 \\
\text { Jumlah }\end{array}$ & 250.000 & 1.000 .000 & $\begin{array}{l}1.000 .000 \\
\mathbf{4 . 4 0 0 . 0 0 0}\end{array}$ \\
\hline \multicolumn{5}{|c|}{ Total biaya tetap per produk dari 30 produk } & 146.666 \\
\hline
\end{tabular}

Tabel 4. Rincian biaya variabel bakwan ikan 12 produksi bulan-1

\begin{tabular}{|c|c|c|c|c|c|}
\hline Uraian & Satuan & Jumlah & $\begin{array}{c}\text { Harga } \\
\text { Satuan } \\
(R p)\end{array}$ & $\begin{array}{c}\text { Jumlah } \\
\text { (Rp) }\end{array}$ & $\begin{array}{c}\text { Jumlah Bulan } \\
{ }^{-}(R p)\end{array}$ \\
\hline Ikan Bandeng & $\mathrm{Kg}$ & 1 & 28.000 & 28.000 & 336.000 \\
\hline Tepung terigu & $\mathrm{Kg}$ & 0,35 & 35.000 & 12.250 & 150.000 \\
\hline Tepung tapioka & $\mathrm{Kg}$ & 0,15 & 8.000 & 1.200 & 14.400 \\
\hline Telur ayam & $\mathrm{Kg}$ & 0,25 & 20.000 & 5.000 & 60.000 \\
\hline Wortel & $\mathrm{Kg}$ & 0,5 & 5.000 & 2.500 & 30.000 \\
\hline Daun bawang & Akar & 1 & 200 & 200 & 2.400 \\
\hline Seledri & Batang & 2 & 250 & 500 & 12.500 \\
\hline Garam & $\mathrm{Kg}$ & 0.02 & 8.000 & 160 & 1.920 \\
\hline Gula pasir & $\mathrm{Kg}$ & 0.4 & 11.000 & 4.400 & 52.800 \\
\hline Susu dancow & Sachet & 1 & 2.500 & 2.500 & 30.000 \\
\hline Merica & $\mathrm{Kg}$ & 0,1 & 100.000 & 10.000 & 120.000 \\
\hline Es batu & Liter & 2 & - & - & . \\
\hline Label $^{*}$ & Lembar & 12 & 250 & 3000 & 36.000 \\
\hline Kemasan** & Lembar & 12 & 80 & 960 & 11.520 \\
\hline Tenaga kerja & Orang & 1 & 52.000 & 52.000 & 624.000 \\
\hline \multicolumn{3}{|c|}{ Jumlah } & & 63.670 & 1.481 .540 \\
\hline
\end{tabular}

\section{HASIL DAN PEMBAHASAN}

\section{Hasil}

Analisis usaha terdiri dari modal investasi, biaya penyusutan, biaya produksi, biaya variabel, Pendapatan, Keuntungan, BEP, R/C, ROI dan PP. Biaya investasi merupakan biaya yang dikeluarkan untuk memproduksi usaha pengolahan dari 30 produk olahan termasuk ke tujuh produk yang menjadi kajian dalam penelitian ini. Rincian biaya investasi pengolahan produk olahan hasil perikanan CV Fania disajikan pada Tabel 1.
Jumlah biaya investasi secara keseluruhan yaitu sebesar $R p$ 156.591.826 dengan penyusutan sebesar Rp. 1.133.335. Setiap satu produk mendapat beban biaya investasi sebesar Rp. 5.418.625 dengan penyusutan $\mathrm{Rp}$. 40.505, kecuali olahan otak-otak bandeng dan galantin biaya investasi sebesar Rp. 6.668.625 dan penyusutan sebesar Rp. 65.852. Produk olahan bakwan, bakso, nugget, kaki naga dan otak-otak ikan menggunakan alat-alat yang sama maka biaya investasi dan penyusutan untuk kelima produk ini sama. Olahan otak-otak bandeng dan 
Tabel 5. Rincian biaya variabel bakso ikan 12 produksi bulan-1

\begin{tabular}{|c|c|c|c|c|c|}
\hline Uraian & Satuan & Jumlah & $\begin{array}{c}\text { Harga } \\
\text { Satuan } \\
(\mathrm{Rp})\end{array}$ & Jumlah & $\begin{array}{c}\text { Jumlah } \\
\text { Bulan }^{-1} \\
\text { (Rp) }\end{array}$ \\
\hline Ikan Bandeng & $\mathrm{Kg}$ & 10 & 28.000 & 280.000 & 3.360 .000 \\
\hline Tepung tapioka & $\mathrm{Kg}$ & 3 & 8.000 & 24.000 & 288.000 \\
\hline Tepung aren & $\mathrm{Kg}$ & 0,5 & 10.000 & 5.000 & 60.000 \\
\hline Bawang merah & $\mathrm{Kg}$ & 0,5 & 15.000 & 7.500 & 90.000 \\
\hline Bawang putih & $\mathrm{Kg}$ & 0,5 & 25.000 & 12.500 & 150.000 \\
\hline Merica & $\mathrm{Kg}$ & 0,1 & 100.000 & 10.000 & 120.000 \\
\hline Garam & $\mathrm{Kg}$ & 0,5 & 8.000 & 4.000 & 48.000 \\
\hline Bumbu penyedap & $\mathrm{Kg}$ & 0,2 & 30.000 & 6.000 & 72.000 \\
\hline Putih telur & $\mathrm{Kg}$ & 1,5 & 19.000 & 28.000 & 336.000 \\
\hline Minyak goreng & Liter & 1 & 12.000 & 12.000 & 144.000 \\
\hline Label & Lembar & 60 & 250 & 15.000 & 180.000 \\
\hline Kemasan & Lembar & 60 & 80 & 4.800 & 57.600 \\
\hline Tenaga kerja & $\begin{array}{l}\text { Orang } \\
\text { Jumlah }\end{array}$ & 1 & 52.000 & $\begin{array}{r}52.000 \\
408.800\end{array}$ & $\begin{array}{r}624.000 \\
5.529 .600\end{array}$ \\
\hline
\end{tabular}

Tabel 6. Rincian biaya variabel nugget ikan 8 produksi bulan ${ }^{-1}$

\begin{tabular}{lccrrr}
\hline \multicolumn{1}{c}{ Uraian } & Satuan & Jumlah & $\begin{array}{c}\text { Harga } \\
\text { Satuan (Rp) }\end{array}$ & Jumlah & $\begin{array}{c}\text { Jumlah } \\
\text { Bulan-1 } \\
\text { (Rp) }\end{array}$ \\
\hline Ikan Bandeng & $\mathrm{Kg}$ & 10 & 28.000 & 280.000 & 2.240 .000 \\
Tepung sagu & $\mathrm{Kg}$ & 1,5 & 8.000 & 12.000 & 96.000 \\
Bawang merah & $\mathrm{Kg}$ & 0,5 & 15.000 & 7.500 & 60.000 \\
Bawang putih & $\mathrm{Kg}$ & 0,5 & 25.000 & 12.500 & 100.000 \\
Lada bubuk & $\mathrm{Kg}$ & 0,1 & 100.000 & 10.000 & 80.000 \\
Garam & $\mathrm{Kg}$ & 0,2 & 8.000 & 1.600 & 12.800 \\
Bumbu penyedap & $\mathrm{Kg}$ & 0,2 & 30.000 & 6.000 & 48.000 \\
Telur ayam & $\mathrm{Kg}$ & 5 & 20.000 & 100.000 & 800.000 \\
Santan/kelapa & $\mathrm{Butir}$ & 5 & 4.000 & 20.000 & 160.000 \\
Tepung terigu & $\mathrm{Kg}$ & 7,5 & 10.000 & 75.000 & 600.000 \\
protein tinggi & $\mathrm{Kg}$ & 2,5 & 12.000 & 30.000 & 240.000 \\
Tepung maizena & $\mathrm{Kg}$ & 0,3 & 25.000 & 7.500 & 60.000 \\
Baking soda & $\mathrm{Kg}$ & 20.000 & 40.000 & 32.000 \\
Gas isi ulang & Tabung & 2 & 2.000 & 60.000 & 480.000 \\
Bread crumb & $\mathrm{Kg}$ & 3 & 1.000 & 3.300 & 26.400 \\
Gula pasir & $\mathrm{Kg}$ & 0,3 & 1.000 & 288.000 \\
Minyak goreng & Liter & 3 & 12.000 & 36.000 & 250 \\
Label & Lembar & 60 & 250 & 15.000 & 120.000 \\
Kemasan & Lembar & 60 & 80 & 4.800 & 38.400 \\
Tenaga kerja & Orang & 1 & 52.000 & 52.000 & 624.000 \\
& JUMLAH & & & $\mathbf{7 2 1 . 2 0 0}$ & $\mathbf{6 . 3 9 3 . 0 0 0}$ \\
\hline
\end{tabular}

galantin berbeda dengan kelima olahan sebelumnya karena terdapat beberapa alat yang hanya digunakan oleh kedua produk olahan tersebut. Selanjutnya ditetapkan Biaya Tetap (Fix Cost) dan Biaya Tidak Tetap (Variable Cost) produk-produk tersebut dapat dilihat pada Tabel 3 :

Total biaya tetap per produk didapatkan dari biaya penyusutan dijumlahkan dengan biaya tetap yang dikeluarkan setiap bulannya. Sehingga 
Tabel 7. Rincian biaya variabel otak otak ikan 15 produksi bulan ${ }^{-1}$

\begin{tabular}{lccrrr}
\hline \multicolumn{1}{c}{ Uraian } & Satuan & Jumlah & $\begin{array}{c}\text { Harga } \\
\text { Satuan (Rp) }\end{array}$ & Jumlah & $\begin{array}{c}\text { Jumlah } \\
\text { Bulan }^{-1}(\mathbf{R p})\end{array}$ \\
\hline Ikan Bandeng & $\mathrm{Kg}$ & 3 & 28.000 & 84.000 & 1.260 .000 \\
Tepung Tapioka & $\mathrm{Kg}$ & 0.17 & 8.000 & 1.360 & 20.400 \\
Terigu & $\mathrm{Kg}$ & 0.3 & 35.000 & 10.500 & 157.500 \\
Bawang putih & $\mathrm{Kg}$ & 0.25 & 25.000 & 6.250 & 93.750 \\
Gula Pasir & $\mathrm{Kg}$ & 0.165 & 11.000 & 1.815 & 27.225 \\
Garam & $\mathrm{Kg}$ & 0.18 & 8.000 & 1.440 & 21.600 \\
Soda Kue & $\mathrm{Kg}$ & 0.1 & 25.000 & 2.500 & 37.500 \\
Daun Bawang & $\mathrm{Akar}$ & 1 & 2.000 & 2.000 & 30.000 \\
Label & Lembar & 24 & 250 & 6.000 & 90.000 \\
Kemasan & Lembar & 24 & 75 & 1.800 & 27.000 \\
Tenaga kerja & Orang & 1 & 52.000 & 52.000 & 624.000 \\
& Total & & & $\mathbf{1 1 7 . 6 6 5}$ & $\mathbf{2 . 3 8 8 . 9 7 5}$ \\
\hline
\end{tabular}

Tabel 8. Rincian biaya variabel kaki naga 10 produksi bulan ${ }^{-1}$

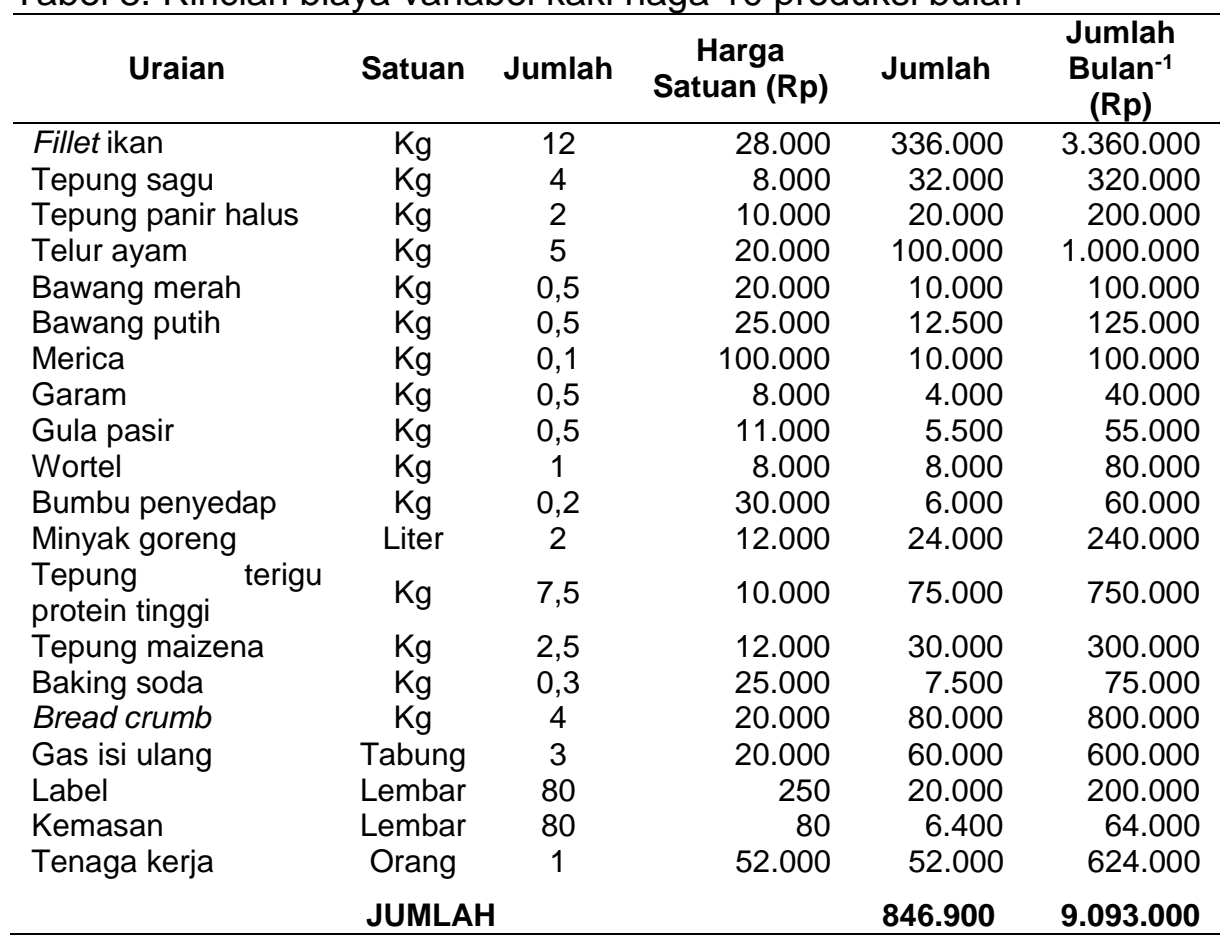

biaya tetap per produk sebesar Rp.

187.171 kecuali produk olahan otak-otak bandeng dan galantin sebesar Rp. 212.518. Biaya tidak tetap pada setiap produk dapat dilihat di Tabel 4. 
Tabel 9. Rincian biaya variabel otak-otak bandeng 25 produksi bulan ${ }^{-1}$

\begin{tabular}{lccrrr}
\hline \multicolumn{1}{c}{ Uraian } & Satuan & Jumlah & $\begin{array}{c}\text { Harga } \\
\text { Satuan (Rp) }\end{array}$ & Jumlah & $\begin{array}{c}\text { Jumlah } \\
\text { Bulan } \\
\text { (Rp) }\end{array}$ \\
\hline lkan bandeng & $\mathrm{Kg}$ & 20 & 20.000 & 560.000 & 14.000 .000 \\
$\begin{array}{l}\text { Tepung panir } \\
\text { halus }\end{array}$ & $\mathrm{Kg}$ & 4 & 10.000 & 40.000 & 1.000 .000 \\
Telur ayam & $\mathrm{Kg}$ & 6 & 20.000 & 120.000 & 3.000 .000 \\
Minyak goreng & $\mathrm{Liter}$ & 4 & 12.000 & 48.000 & 1.200 .000 \\
Bawang merah & $\mathrm{Kg}$ & 0,5 & 20.000 & 10.000 & 250.000 \\
Bawang putih & $\mathrm{Kg}$ & 0,5 & 25.000 & 12.500 & 312.500 \\
Kemiri & $\mathrm{Kg}$ & 0,5 & 40.000 & 20.000 & 500.000 \\
Gula merah & $\mathrm{Kg}$ & 0,5 & 16.000 & 8.000 & 200.000 \\
Pala & $\mathrm{Kg}$ & 0,1 & 100.000 & 10.000 & 250.000 \\
Merica & $\mathrm{Kg}$ & 0,1 & 100.000 & 10.000 & 250.000 \\
Garam & $\mathrm{Kg}$ & 0,5 & 8.000 & 4.000 & 100.000 \\
Bumbu penyedap & $\mathrm{Kg}$ & 0,2 & 30.000 & 6.000 & 150.000 \\
Gas isi ulang & Tabung & 3 & 20.000 & 60.000 & 1.500 .000 \\
Label & Lembar & 90 & 1000 & 90.000 & 2.250 .000 \\
Kemasan & Lembar & 90 & 43.000 & 110.571 & 2.764 .275 \\
Tenaga kerja & Orang & 1 & 52.000 & 52.000 & 624.000 \\
& JUMLAH & & $\mathbf{1 . 1 0 9 . 0 7 1}$ & $\mathbf{2 8 . 3 5 0 . 2 7 5}$ \\
\hline
\end{tabular}

Tabel 10. Rincian biaya variabel galantin bandeng 25 produksi bulan ${ }^{-1}$

\begin{tabular}{lccrrr}
\hline \multicolumn{1}{c}{ Uraian } & Satuan & Jumlah & $\begin{array}{c}\text { Harga } \\
\text { Satuan (Rp) }\end{array}$ & Jumlah & \multicolumn{1}{c}{$\begin{array}{c}\text { Jumlah } \\
\text { Bulan'-1 (Rp) }\end{array}$} \\
\hline Ikan Bandeng & $\mathrm{Kg}$ & 2,5 & 28.000 & 70.000 & 1.750 .000 \\
Telur ayam & $\mathrm{Kg}$ & 3 & 20.000 & 60.000 & 1.500 .000 \\
Tepung panir & $\mathrm{Kg}$ & 2 & 31.000 & 62.000 & 1.550 .000 \\
Bawang putih & $\mathrm{Kg}$ & 0,2 & 25.000 & 5.000 & 125.000 \\
Bawang merah & $\mathrm{Kg}$ & 0,2 & 17.000 & 3.400 & 85.000 \\
Garam & $\mathrm{Kg}$ & 0.1 & 8.000 & 800 & 20.000 \\
Kemiri & $\mathrm{Kg}$ & 0,1 & 48.000 & 4.800 & 120.000 \\
Merica & $\mathrm{Kg}$ & 0,05 & 100.000 & 5.000 & 125.000 \\
Gula merah & $\mathrm{Butir}$ & 2 & 1.600 & 3.200 & 80.000 \\
Pala & $\mathrm{Kg}$ & 0,05 & 100.000 & 5.000 & 125.000 \\
Label & Lembar & 27 & 250 & 6.000 & 150.000 \\
Plastik Vacum & Lembar & 27 & 43.000 & 33.171 & 829.275 \\
Tenaga kerja & Orang & 1 & 52.000 & 52.000 & 624.000 \\
& Total & & & $\mathbf{2 5 8 . 3 7 1}$ & $\mathbf{7 . 0 8 3 . 2 7 5}$ \\
\hline
\end{tabular}

Tabel 11. Total biaya produksi

\begin{tabular}{lcccc}
\hline \multicolumn{1}{c}{ Jenis Produk } & $\begin{array}{c}\text { Rumus (Rp) } \\
\text { BT + BV }\end{array}$ & $\begin{array}{c}\text { Biaya Produksi } \\
\text { bulan }\end{array}$ & $\begin{array}{c}\text { Rumus (Rp) } \\
\text { BP + JP })\end{array}$ & $\begin{array}{c}\text { Modal } \\
\text { bungkus }^{-1}\end{array}$ \\
\hline Bakwan & $187.171+1.481 .540$ & 1.668 .711 & $1.668 .711 / 144$ & 11.588 \\
Bakso & $187.171+5.529 .600$ & 5.716 .771 & $5.716 .771 / 720$ & 7.939 \\
Nugget & $187.171+6.393 .000$ & 6.580 .171 & $6.580 .171 / 480$ & 13.708 \\
Kaki Naga & $187.171+9.093 .000$ & 9.280 .171 & $9.280 .171 / 800$ & 11.600 \\
Otak-otak Ikan & $187.171+2.388 .975$ & 2.576 .146 & $2.576 .146 / 360$ & 7.155 \\
Otak-otak Bandeng & $212.518+28.350 .000$ & 28.562 .518 & $28.562 .518 / 2250$ & 12.694 \\
Galantin & $212.518+7.083 .275$ & 7.295 .793 & $7.295 .793 / 675$ & 10.808 \\
\hline
\end{tabular}


Tabel 12. Tabel rekapan hasil analisis usaha

\begin{tabular}{|c|c|c|c|c|c|}
\hline Nama Produk & $\begin{array}{c}\text { Harga } \\
\text { kemasan } \\
-1(\mathrm{Rp}) \\
\end{array}$ & $\begin{array}{c}\text { Produksi } \\
\text { bulan }^{-1} \\
\text { (Bungkus) }\end{array}$ & $\begin{array}{l}\text { Pendapatan } \\
\text { bulan }^{-1}(\mathrm{Rp})\end{array}$ & $\begin{array}{l}\text { Rumus (Rp) } \\
\text { PP + BP }\end{array}$ & $\begin{array}{l}\text { Keuntungan } \\
\text { bulan }^{-1}(\mathrm{Rp})\end{array}$ \\
\hline Bakwan & 16.000 & 144 & & 68.711 & 289 \\
\hline Bakso Ikan & 16.000 & 720 & 11. & 16.771 & \\
\hline Nugget & 16.000 & 480 & 00 & 580.171 & \\
\hline Kaki Naga & 16.000 & 800 & 12.8 & 12.800 .000 & 329 \\
\hline Otak otak Ikan & 22.000 & 2250 & 5.760 .000 & $5.760 .000-2.576 .146$ & 3.183 .854 \\
\hline Galantin & 20.000 & 675 & 13.500 .000 & $13.500 .000-7.295 .793$ & 6.204 .207 \\
\hline $\begin{array}{l}\text { Otak-otak Bandeng } \\
\text { Total produks }\end{array}$ & $\mathbf{s i}^{16.000}$ & $\begin{array}{c}360 \\
4.629\end{array}$ & $\begin{array}{r}49.500 .000 \\
103.064 .000\end{array}$ & $\begin{array}{c}49.500 .000-28.562 .518 \\
\text { Total Keuntungan }\end{array}$ & $\begin{array}{l}20.937 .482 \\
\mathbf{4 1 . 3 8 3 . 7 1 9}\end{array}$ \\
\hline
\end{tabular}

Tabel 13. Perbandingan analisis usaha

\begin{tabular}{|c|c|c|c|c|c|c|}
\hline \multirow[b]{2}{*}{ Nama Produk } & \multicolumn{2}{|c|}{ BEP } & \multirow[b]{2}{*}{$\mathrm{R} / \mathrm{C}$} & \multirow[b]{2}{*}{$\begin{array}{l}\text { ROI } \\
\text { (\%) }\end{array}$} & \multirow[b]{2}{*}{$\begin{array}{c}\text { PP } \\
\text { (Bulan) }\end{array}$} & \multirow[b]{2}{*}{$\begin{array}{l}\text { Keuntungan } \\
\text { bulan }^{-1}(\mathbf{R p})\end{array}$} \\
\hline & $\begin{array}{c}\text { Biaya } \\
\text { Rp }\end{array}$ & $\begin{array}{c}\text { Unit } \\
\text { Bungkus }\end{array}$ & & & & \\
\hline Bakwan & 519.919 & 36 & 1,38 & 38 & 8,53 & 635.289 \\
\hline Bakso & 359.944 & 23 & 2,01 & 101 & 0,93 & 5.803 .229 \\
\hline Nugget & 1.101 .005 & 70 & 1,16 & 16 & 4,93 & 1.099 .829 \\
\hline Kaki Naga & 645.417 & 40 & 1,37 & 37,9 & 1,54 & 3.519 .829 \\
\hline Otak-otak Ikan & 317.238 & 20 & 2,23 & 123 & 1,68 & 3.183 .854 \\
\hline Galantin & 442.745 & 28 & 1,85 & 85 & 1,07 & 6.204 .207 \\
\hline Otak-otak Bandeng & 494.227 & 23 & 1,73 & 73 & 0,24 & 20.937.482 \\
\hline
\end{tabular}

Perhitungan biaya produksi dan modal per bungkus dari usaha pengolahan ini untuk tujuh produk dapat dilihat pada Tabel 11. Rekapan usaha produk olahan dalam satu bulan dapat dilihat pada Tabel 12, dimana pendapatan per bulan (PP) dikurangi biaya produksi per bulan (BP).

\section{Pembahasan}

\section{Biaya Produksi}

Biaya investasi dibedakan menjadi dua jenis dalam pelaksanaannya yaitu investasi nyata dan investasi finansial. Investasi nyata merupakan investasi dalam harga tetap (fixed asset) seperti tanah, bangunan, peralatan atau mesinmesin. Adapun investasi finansial dalam bentuk kontrak kerja, pembelian saham atau obligasi dan surat-surat berharga lainnya (Rifani 2015). Biaya investasi di CV. Fania Food merupakan investasi nyata yang terdiri dari bangunan, mesin dan peralatan lainnya. Setiap olahan memiliki biaya investasi dan biaya penyusutan yang berbeda berdasarkan alat yang digunakan dalam produksinya. Biaya penyusutan juga di pengaruhi oleh jangka usia peralatan yang digunakan. Biaya penyusutan aset berpengaruh signifikan terhadap laba dan metode garis lurus yang paling dominan berpengaruh terhadap laba (Wairooy 2017).

Biaya investasi pada olahan bakwan, bakso, nugget, kaki naga dan 
otak-otak ikan sebesar Rp. 5.418.625 berbeda dengan olahan galantin dan otak-otak bandeng sebesar Rp. 6.668.625 dikarenakan terdapat beberapa alat yang tidak digunakan pada kelima olahan tersebut. Nilai biaya pada aset (biaya investasi) akan berpengaruh terhadap biaya penyusutan pada aset tersebut sesuai dengan Jangka Usia Ekonomis (JUE) pada aset yang digunakan. Semakin tinggi biaya penyusutan maka semakin tinggi biaya tetap dan laba semakin rendah, begitupun sebaliknya (Avisha 2018). Perbedaan biaya investasi tiap olahan akan mempengaruhi nilai dari biaya penyusutan dan biaya tetap perbulan tiap olahan.

H. Susanto (2010), menyatakan biaya produksi dibedakan menjadi dua yaitu biaya tetap dan biaya tidak tetap. Biaya tetap dicirikan dengan biaya yang pengeluarannya selalu sama dalam satuan waktu tertentu. Adapun biaya tidak tetap dicirikan dengan pengeluaran biaya produksi yang tidak selalu sama tergantung dari bahan ataupun alat yang digunakan dalam produksinya. Biaya variabel (tidak tetap) pada ketujuh olahan berbeda satu sama lain, hal ini dipengaruhi oleh penggunaan jumlah dan takaran bahan yang digunakan berbeda setiap olahan. Pada ketujuh olahan menggunakan bahan baku yang sama yaitu ikan bandeng. Ikan bandeng digunakan karena ketersediaan bahan baku yang selalu ada, harga yang murah yaitu Rp. $28.000 \mathrm{~kg}^{-1}$, kandungan gizi yang tinggi serta rasa daging gurih yang diminati oleh masyarakat. Hal ini sesuai pernyataan Fitri (2016), ikan bandeng memiliki beberapa keunggulan di mata masyarakat diantaranya rasa yang enak dan gurih, rasa daging netral (tidak asin), harga yang terjangkau pada lapisan masyarakat serta daging yang tidak mudah hancur pada saat diolah atau dimasak.

Biaya variabel tertinggi berturutturut terdapat pada olahan Otak-otak Bandeng sebesar Rp. 28.350.000, Kaki Naga sebesar Rp. 9.093.000, Galantin sebesar Rp. 7.083.275, Nugget sebesar Rp. 6.393.000, Bakso sebesar Rp. 5.529.600, Otak-otak Ikan sebesar 2.388.975 serta olahan bakwan sebesar Rp. 1.481.540. Biaya Variabel Otak-otak bandeng dipengaruhi oleh banyaknya bahan baku yang digunakan dalam satu kali produksi yaitu sebanyak $20 \mathrm{~kg}$. Tingginya permintaan pada olahan tersebut menyebabkan penggunaan bahan baku yang lebih banyak dibanding dengan olahan yang lain. Sehingga frekuensi produksi olahan lebih tinggi disertai dengan biaya produksi pada olahan.

Biaya tetap perbulan sebesar Rp. 187.171 kecuali untuk olahan otak-otak bandeng dan galantin yaitu sebesar Rp. 
212.518. Perbedaan biaya tetap disebabkan oleh biaya beberapa alat produksi yang hanya digunakan oleh kedua olahan tersebut. Total biaya produksi tertinggi dengan menjumlahkan biaya tetap dengan biaya variabel yaitu pada olahan Otak-otak Bandeng sebesar Rp. 28.562.518.

Rahayu (2013), menjelaskan harga pokok produksi atau modal per produk merupakan biaya produksi yang berkaitan dengan barang-barang yag digunakan dalam periode waktu tertentu, terdiri dari biaya bahan baku, biaya tenaga kerja langsung dan biaya yang berkaitan dengan proses produksi selain bahan dan tenaga kerja. Adapun cara perhitungan harga pokok produksi menurut (Mulyadi 2010), dapat dilakukan dengan dua cara dengan full costing dan variable costing. Full costing adalah penentuan harga pokok produksi dengan membebankan kepada seluruh biaya produksi, baik yang berprilaku maupun variabel pada produk tersebut. Adapun variabel costing merupakan penentuan harga pokok produksi yang hanya membebankan pada biaya produksi yang berprilaku atau tidak termasuk biaya tetap pada perusahaan tersebut.

Perhitungan harga pokok produksi di CV. Fania Food lebih dikenal dengan sebutan modal per produk. Perhitungan modal per produk dilakukan dengan cara full costing yaitu menjumlahkan seluruh biaya produksi dibagi dengan jumlah produk yang dihasilkan dalam satu bulan produksi. Modal per produk yang didapatkan pada ketujuh olahan di antaranya bakwan sebesar Rp. 11.588, bakso sebesar Rp. 7.939, nugget sebesar Rp. 13.708, kaki naga sebesar Rp. 11.600, otak-otak ikan sebesar Rp. 7.155, otak-otak bandeng sebesar Rp. 12.694 dan galantin sebesar Rp. 10.808 . Produk olahan dengan modal per produk tertinggi yaitu olahan nugget sebesar $\mathrm{Rp}$. 13.708 dengan biaya produksi sebesar Rp. 6.580.171 serta produk yang dihasilkan sebanyak 480 bungkus.

\section{Pendapatan dan Keuntungan}

Penentuan harga jual dalam mendapatkan keuntungan menurut Kotler and Keller (2009) menyatakan harga jual adalah sejumlah nilai uang ditukar konsumen atas manfaat-manfaat atas barang atau jasa tersebut. Menurut Swastha (2010), metode penentuan harga jual salah satunya yaitu dengan cara penentuan harga oleh produsen itu sendiri. Proses penetapan harga dimulai dengan menghitung biaya per unit yang telah dihasilkan kemudian menambahkan mark up atau selisih keuntungan tertentu. Penetapan harga per produk dari ketujuh olahan dengan cara memperhatikan kondisi pasar dan keuntungan yang akan didapatkan. Harga per produk sebesar Rp. 16.000 
kecuali untuk olahan Otak-otak ikan sebesar Rp. 22.000 dan galantin sebesar Rp. 20.000.

Pendapatan merupakan jumlah pemasukan yang diterima dan keuntungan usaha merupakan pengurangan total pendapatan dengan total biaya produksi (Rahim dan Hastuti 2007). Pendapatan tertinggi dari ketujuh olahan ini terdapat pada olahan otakotak bandeng sebesar Rp. 49.500.000 dengan biaya produksi sebesar Rp. 28.562.518 sehingga keuntungan yang diperoleh dalam satu bulan sebesar Rp. 20.937.482. Keuntungan total yang di dapatkan oleh CV. Fania Food dalam satu bulan dari ketujuh olahan yaitu sebesar Rp. 41.383.719. Menurut Wayan (2017), peningkatan pendapatan dapat dilakukan dengan peningkatan kualitas produksi, pemanfaatan media iklan sebagai pangsa pasar, penetapan harga yang stabil sesuai mata uang dan inovasi produk dengan pemanfaatan teknologi.

Khairani and Pratiwi (2018) menyatakan bahwa peningkaan pendapatan dapat dilakukan dengan strategi promosi yang mengacu pada komunikasi pemasaran tradisional (majalah, surat kabar dan lain-lain) dan pemasaran modern (situs, media sosial dan toko online). Kesesuaian selera konsumen dengan konten promosi pemasaran yang dilakukan akan menimbulkan permintaan pada suatu produk. Peningkatan permintaan tersebut yang akan mendorong kegiatan produksi diakibatkan oleh adanya kenaikan penjualan. Kelebihan promosi melalui media sosial lebih efisien karena tidak membutuhkan biaya dan penyebarannya lebih cepat serta jangkauan media sosial sangat luas.

\section{Perbandingan Analisis Usaha}

Perbandingan analisis usaha dari ketujuh produk olahan di CV. Fania Food dapat dilihat pada Tabel 13. Nilai BEP yang ditunjukkan pada tabel diatas menjelaskan titik impas produksi baik dari segi besarnya biaya ataupun banyaknya unit yang diproduksi. Menurut Asnidar dan Asrida (2017), BEP merupakan analisis yang dilakukan untuk menentukan dan mencari titik impas dimana jumlah barang atau jasa yang harus dijual ataupun di produksi. BEP juga digunakan untuk menganalisis besarnya biaya produksi yang dikeluarkan sehingga mencapai titik impas serta mengetahui besarnya keuntungan yang akan diterima.

BEP setiap olahan berbeda satu sama lain setiap produknya, dimana BEP (Rp) dan BEP (Unit) tertinggi terdapat pada olahan nugget sebesar Rp. 1.101.005 dan 70 bungkus, kaki naga sebesar Rp. 645.417 dan 40 bungkus, bakwan sebesar Rp. 519.919 dan 36 bungkus, otak-otak bandeng Rp. 
494.227 dan 23, galantin sebesar Rp. 442.745 dan 28 bungkus, bakso Rp. 359.944 dan 23 bungkus serta otak-otak Ikan sebesar Rp. 317.238 dan 20 bungkus. Data tersebut merupakan titik impas setiap olahan dimana produk olahan tersebut tidak mengalami keuntungan dan kerugian.

Tabel 13 menunjukkan semua olahan dapat dinyatakan layak dengan nilai $\mathrm{R} / \mathrm{C}$ ratio diatas 1 yaitu bakwan $(1,38)$, bakso $(2,01)$, nugget $(1,16)$, kaki naga $(1,37)$, otak-otak ikan $(2,23)$, galantin $(1,85)$, otak-otak bandeng $(1,73)$. Artinya setiap biaya produksi sebanyak Rp. 1 mampu mendapatkan pendapatan sebanyak Rp. 1.38 untuk bakwan, Rp 2.01 untuk bakso, Rp 1.16 untuk nugget, Rp 1.37 untuk kaki naga, Rp 2.23 untuk otak-otak ikan, Rp 1.85 untuk galantin dan Rp 1.73 untuk otakotak bandeng. Hal ini sebagaimana menurut Saparinto (2014) di mana usaha akan dikatakan layak ketika nilai R/C berada di atas satu. Terdapat beberapa faktor dalam penentuan kelayakan usaha. Manope et al (2014) menyatakan faktor tersebut dapat dilihat dari berbagai aspek di antaranya aspek hukum, aspek pasar dan pemasaran, aspek keuangan, aspek teknis/operasi, aspek manajemen dan organisasi, aspek ekonomi sosial serta aspek dampak lingkungan. Adapun aspek yang merupakan aspek inti yaitu aspek ekonomi dan keuangan karena aspek ini menentukan kelayakan usaha dilihat dari segi ekonomi dan keuangan suatu usaha.

Nilai $\mathrm{ROI}$ pada tabel dinyatakan dalam satuan persentase yang berarti nilai keuntungan yang didapatkan dari setiap jumlah uang yang diinvestasikan dalam jangka waktu periode tertentu. Analisis ROI membantu perusahaan untuk mengukur sejauh mana kemampuan usaha atau produk dalam pengembalian modal yang telah ditanam sebelumnya dalam bentuk persentase. Syamsuddin (2009) melaporkan ROI yaitu suatu rasio untuk mengukur kemampuan perusahaan secara menyeluruh dalam mendapatkan keuntungan secara keseluruhan aktiva atau harta yang tersedia didalam perusahaan.

Tabel 13 menunjukkan produk dengan pendapatan lebih besar dari biaya produksi yaitu produk olahan otakotak ikan dengan nilai $R / C$ ratio 2,23 , adapun produk yang mendapatkan keuntungan dan pengembalian biaya investasi paling besar yaitu otak-otak bandeng dengan keuntungan $R p$ 20.937.482 dan pengembalian modal dalam jangka waktu 0,02 tahun atau 0,24 bulan. Semakin besar keuntungan yang diperoleh dan lebih tinggi dari nilai investasi awal maka semakin cepat produk tersebut mengembalikan modal investasi awal. Hermuningsih (2012) 
melaporkan keuntungan atau profitabilitas mempunyai arti penting bagi perusahaan dalam mempertahankan kelangsungan hidup perusahaan tersebut dalam jangka panjang, karena keuntungan tersebut menunjukkan prospek yang baik bagi perusahaan dimasa yang akan datang. Semakin tinggi keuntungan maka semakin tinggi kelangsungan hidup perusahaan dan akan lebih terjamin.

Usaha dengan pengembalian modal investasi paling lama yaitu pada olahan bakwan selama 8,53 bulan produksi. Hal ini disebebkan oleh keuntungan yang didapatkan oleh olahan ini lebih rendah dari olahan lainnya yaitu sebesar Rp. 7.623.426. Didapatkan biaya investasi olahan bakwan sebesar Rp. 5.590.799, jika dipersentasekan hanya mendapatkan selisih 26,7\%. Berbeda dari olahan lainnya dengan selisih diatas $100 \%$ dalam satu tahun produksi sehingga untuk pengembalian modal investasi lebih lama dibanding olahan yang lain. Lubis dan Zulam (2016) menjelaskan besarnya keuntungan yang diperoleh perusahaan akan menentukan waktu pengembalian modal investasi pada perusahaan tersebut. Angeliend (2011) menjelaskan tingkat pengembalian yang tinggi akan berpeluang untuk membiayai sebagian besar kebutuhan perusahaan dalam pendanaan dengan dana yang dihasilkan secara internal.

\section{SIMPULAN DAN SARAN}

Berdasarkan hasil kajian penelitian yang telah dilaksanakan, didapatkan kesimpulan sebagai berikut :

1. Berdasarkan analisis usaha yang dilakukan didapatkan berbagai perbedaan biaya dan pendapatan tiap olahan. Untuk BEP Rupiah tertinggi terdapat pada olahan Nugget sebesar Rp. 1.101.005 dan BEP unit sebanyak 70 bungkus. Pengembalian biaya investasi (PP) dengan jangka waktu paling lama yaitu olahan Bakwan yaitu 8,53 bulan, dikarenakan keuntungan yang didapatkan hampir sama dengan modal awal investasi pada olahan tersebut. Adapun keuntungan terbesar terdapat pada olahan Otakotak Bandeng Rp 20.937.482.

2. Berdasarkan kajian yang telah dilaksanakan, ketujuh produk olahan perikanan di CV. Fania Food layak di produksi sehingga dapat menjadi potensi usaha bagi UKM dengan modal usaha yang relatif rendah.

Berdasarkan hasil kajian penelitian yang telah dilaksanakan, didapatkan saran sebagai berikut :

1. Untuk menekan biaya produksi perllunya mencari sumber bahan baku lain yang lebih dekat dari rumah 
produksi sehingga meminimalisir biaya transportasi.

2. Perlunya pemanfaatan media sosial atau website perusahaan sehingga dapat memaksimalkan pemasaran kepada konsumen.

3. Analisis kelayakan usaha sangat perlu dilakukan oleh perusahaan agar dapat mengetahui dan mengontrol pengeluaran dan pendapatan perusahaan.

\section{DAFTAR PUSTAKA}

Angeliend, Raja Patresia. 2011. "Jurnal Ekonomi Dan Bisnis Analisis Struktur Modal Dan Faktor-Faktor Yang Mempengaruhinya (Studi Pada Sektor Manufaktur di Bursa Efek Indonesia)." Analisis Struktur Modal Dan Faktor-Faktor Yang Mempengaruhinya (Studi Pada Sektor Manufaktur Di Bursa Efek Indonesia) 1-15.

Asnidar dan Asrida. 2017. "Analisis Kelayakan Usaha Home Industry Kerupuk Opak Di Desa Paloh Meunasah Dayah Kecamatan Muara Satu Kabupaten Aceh Utara." Jurnal S. Pertanian 1(1):3947.

Avisha, Reka. 2018. "Penilaian Penyusutan Aset Tetap Serta Dampaknya Pada Laba Pt Prodia Widyahusada Tbk [Skripsi]." UIN Sumatera Utara.
Fitri, Amiza; Anandito, Baskara ;. siswanti. 2016. "Penggunaan Daging dan Tulang Ikan Bandeng (Chanos chanos) pada Stik Ikan Sebagai Makanan Ringan Berkalsium dan Berprotein Tinggi." Jurnal Teknologi Hasil Pertanian 9(2):65-77.

Geffken, Rolf, Hendrik, dan Zulkarnain. 2017. "Analisis Usaha Pengolahan Ikan Asin di Kelurahan Pondok Batu Kecamatan Sarudik Kota Sibolga Provinsi Sumatera Utara." Jurnal Online Mahasiswa (JOM) Bidang Perikanan dan IImu Kelautan 4(1):1-9.

Hasibuan, Putri. 2018. "Analisis Kelayakan Usaha Pengolahan Ikan Asin Gulamah Batu (Pseudocienna amovensis) [Skripsi]." Universitas Sumatera Utara.

Heri. 2017. Melakukan Analisis Kelayakan dan Menyusun Rencana Bisnis Yang Unggul. Jakarta (ID): Gramedia Widiasarana Indonesia (Grasindo).

Hermuningsih, Sri. 2012. "Pengaruh Profitabilitas, Size Terhadap Nilai Perusahaan dengan Sruktur Modal Sebagai Variabel Intervening." Siasat Bisnis 16:232-42.

Khairani, Siti dan Raisa Pratiwi. 2018.

"Peningkatan Omset Penjualan Melalui Diversifikasi Produk dan Strategi Promosi Pada UMKM 
Kerajinan Souvenir Khas

Palembang." CARADDE: Jurnal Pengabdian Kepada Masyarakat 1(1):36-43.

Kotler, Philip dan Kevin Lane Keller. 2009. "Manajemen Pemasaran Edisi 13." Jakarta: Erlangga.

Kurniawan, Fahmy. 2017. "Analisis

Pengaruh Kualitas Produk, Harga dan Kelompok Acuan Terhadap Keputusan Pembelian Pada CV. Tahu Tuna Pak Ran Pacitan." Universitas Muhammadiyah Surakarta.

Lubis, Pardamen; Zulam, S. B. 2016.

"Analisis Faktor-Faktor Yang Mempengaruhi Permintaan Investasi Di Indonesia." 2(2):14766.

Manope, B F ; Kindangen, P ; Tawas, H. 2014. "Analisa kelayakan usaha komoditas biji dan fuli pala melalui penilaian aspek finansial pada pedagang pengumpul 'Kios Chandra' di Pulau Siau." Jurnal Riset Ekonomi, Manajemen, Bisnis dan Akuntansi 2(4):320-30.

Mulyadi. 2010. Akuntansi Biaya Edisi 5. Yogyakarta (ID): Universitas Gadjah Mada.

Rahardi, F., K. Regina, dan Nazaruddin. 2008. Agribisnis Perikanan. Jakarta (ID): Penebar Swadaya.

Rahayu, Sri. 2013. "Analisis Perhitungan Harga Pokok Produksi dan
Pengelolaan Modal Kerja pada

Katering Sehati." 1:80.

Rahim, Abd dan DRD Hastuti. 2007. Ekonomi Pertanian. Jakarta (ID): Penebar Swadaya.

Rifani, Akhmad. 2015. "Analisis Kelayakan Finansial Usaha Peternakan Ayam Pedaging di Sentra Produksi Ayam Kabupaten Lampung Tengah (Studi Kasus di Sentra Produksi Ayam Kecamatan Kalirejo)." Universitas Lampung.

Saparinto, Cahyo. 2014. Bisnis ikan konsumsi di lahan sempit. Jakarta (ID): Penebar Swadaya Grup.

Susanto, Eko. 2010. "Pengolahan Bandeng (Chanos-chanos) Duri Lunak."

Susanto, H. 2010. Teori Biaya Produksi. Jakarta (ID): Gramedia.

Swastha, Basu. 2010. Manajemen Penjualan Edisi 3. Yogyakarta (ID): Badan Penerbit Fakultas Ekonomi. Syamsuddin, Lukman. 2009. Manajemen Keuangan Perusahaan. Jakarta (ID): Raja Grafindo Persada.

Wairooy, Ali. 2017. "Pengaruh Biaya Penyusutan Aset Tetap terhadap Laba pada PT . Bank Sulselbar." Jurnal Office 3(1):1-6.

Wijaya, Wayan, Yulianeu Yulianeu, Tsalis Syaifuddin, dan Heru Sri Wulan. $2017 . \quad$ "Strategi Pengembangan Usaha CV. Steba Advertising Semarang dalam 
Meningkatkan Pendapatan."

Journal of Management 3(3).

Yudaswara, Refki. 2018. "Analisis

Kelayakan Usaha Produk Olahan

Berbahan Baku Ikan Nila

(Oreochromis niloticus) (Studi

Kasus di CV Sakana Indo Prima

Kota Depok)." Jurnal Perikanan

Kelautan 9(1):104-11. 